\title{
Influence of sports compression textiles on endurance running performance
}

\author{
Martin Harnisch*, Anke Klepser, Edith Classen, Jan Beringer, Andreas Schmidt \\ From 15th International Conference on Environmental Ergonomics (ICEE XV) \\ Portsmouth, UK. 28 June - 3 July 2015
}

\begin{abstract}
Introduction
Sports compression textiles are very popular, especially in endurance sports like triathlon and marathon running [1]. It is well known, that medical compression stockings reduce the expansion of veins and a compressive gradient to the heart enhances venous blood flow [1-3]. During sports compressive textiles reduce wobbling masses, muscle vibration and swelling [4]. Therefore compression should lead to better endurance performance, but the benefit on endurance performance is not clearly proved, e.g. Kemmler et al. [5] found a benefit by compression textiles while Sperlich et al. [1] did not.
\end{abstract}

\section{Methods}

Four compression stockings/calf sleeves with different compression and compression gradients as well a combination of compression stocking with compression thigh sleeve were tested against short sleeved sportswear without compression. Ten experienced runners $(44.6 \pm 4.5$ years) participated in running trials on a treadmill in a climatic room $\left(\mathrm{T}_{\mathrm{a}}=23 \pm 0.2{ }^{\circ} \mathrm{C}, \mathrm{RH}_{\mathrm{a}}=56 \pm 6 \% \mathrm{rh}\right)$. An incremental test was performed to find individual running speed. The main test included $40 \mathrm{~min}$ at $70 \%$ of maximum oxygen consumption followed by $5 \mathrm{~min}$ at speed of penultimate increment. Arterial lactate concentration, oxygen consumption, heart rate, core temperature, skin temperature and humidity and weight loss were recorded. Subjects gave feedback on temperature, humidity, compression, exertion and general perception.

\section{Results}

Statistical differences could not be found for heart rate, oxygen consumption and lactate concentration when comparing different compression textiles and common sportswear. Core temperature, mean whole body temperature

\footnotetext{
* Correspondence: m.harnisch@hohenstein.de

Hohenstein Institut fuer Textilinnovation gGmbH, Boennigheim, Germany
}

and humidity were not increased when wearing compression textiles in comparison to common short sleeved sportswear. But temperature and humidity at calf and thigh were higher when covered by compression textiles. Furthermore weight/sweat loss was not significantly higher when wearing compression textiles and efficiency of evaporation (ratio of produced to evaporated sweat) was not affected. Perception of temperature and humidity was not worse in comparison to common sportswear, but compression at legs made subjects feel better and less exhausted.

\section{Discussion}

Compression textiles had no influence on physiological parameters describing endurance performance, e.g. heart rate, oxygen consumption and lactate, what corresponds with findings by Sperlich et al. [1]. Furthermore it was found that this is independent of compression and compression gradient provided by stockings or sleeves for calve and thigh. On the other hand it could be shown, that an additional clothing layer by compression textiles did not lead to higher thermal stress. In addition subjects felt less exhausted when wearing compression textiles, at the end of the series a ranking of all clothing systems showed a preference for compression textiles by subjects in comparison to standard sportswear.

\section{Conclusion}

There is no physiological evidence for a benefit of compression textiles on running endurance. On the other hand compression textiles do not add thermal stress, show a psychological benefit and compression makes subjects feel less exhausted.

\section{Acknowledgements}

The research project $16868 \mathrm{~N}$ was founded by the Forschungsvereinigung Forschungskuratorium Textil e.V. via grants of the AiF and the Ministry of Economy and Energy. 


\section{References}

1. Sperlich B, Haegele M, Nitsch $S$, et al: Schweizerische Zeitschrift für «Sportmedizin und Sporttraumatologie». 2009, 57(4):132-135.

2. de Marées H: Sportphysiologie. Verlag Sport und Buch Strauss Bochum; 2003.

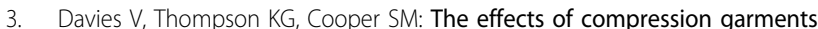
on recovery. J Strength Cond Res 2009, 23(6):1786-1794.

4. Doan BK, Kwon YH, Newton RU, et al: Evaluation of a lower-body compression garment. J Sports Sci 2003, 21(8):601-608.

5. Kemmler W, von Stengel S, Köckritz C, et al: Effect of compression stockings on running performance in men runners. J Strength Cond Res 2009, 23(1):101-105.

\section{doi:10.1186/2046-7648-4-S1-A86}

Cite this article as: Harnisch et al:: Influence of sports compression textiles on endurance running performance. Extreme Physiology \& Medicine 2015 4(Suppl 1):A86.

\section{Submit your next manuscript to BioMed Central} and take full advantage of:

- Convenient online submission

- Thorough peer review

- No space constraints or color figure charges

- Immediate publication on acceptance

- Inclusion in PubMed, CAS, Scopus and Google Scholar

- Research which is freely available for redistribution

Submit your manuscript at www.biomedcentral.com/submit 